\title{
KERAGAAN BENIH IKAN PATIN SIAM (Pangasianodon hypophthalmus) YANG DITEBAR SECARA LANGSUNG DI KOLAM PADA UMUR BERBEDA
}

\author{
Didik Ariyanto, Evi Tahapari, dan Sularto \\ Balai Penelitian Pemuliaan Ikan \\ Jl. Raya 2 Sukamandi, Subang, Jawa Barat 41256 \\ E-mail:didik_ski@yahoo.com
}

(Naskah diterima: 27 Mei 201 1; Disetujui publikasi: 8 Mei 2012)

\begin{abstract}
ABSTRAK
Budidaya ikan patin siam mengalami perkembangan yang cukup pesat sejak keberhasilan pemijahan buatan pada tahun 1981. Pada pelaksanaannya, pembenihan ikan patin siam dilakukan secara indoor hatchery. Dalam sistem tersebut, dibutuhkan nauplii Artemia sebagai pakan awal larva ikan patin siam yang dilanjutkan dengan pemberian Moina dan Daphnia beku serta cacing darah (Tubifex) sebelum pemberian pakan buatan. Hal ini mengakibatkan adanya ketergantungan usaha pembenihan ikan patin siam terhadap pasokan beberapa jenis pakan alami tersebut. Penelitian ini bertujuan untuk mengevaluasi keragaan ikan patin siam yang ditebar di kolam pendederan pada umur yang berbeda. Sasaran yang akan dicapai adalah menghilangkan ketergantungan pembenihan ikan patin siam terhadap pasokan beberapa jenis pakan larva ikan patin siam dan disubstitusi dengan pakan alami yang ada di kolam. Pada percobaan ini, larva patin siam ditebar pada umur 5, 10, dan 15 hari setelah menetas. Larva ditebar di kolam pendederan seluas $200 \mathrm{~m}^{2}$ dengan kepadatan 100 ekor/m². Pemeliharaan dilakukan selama 2 bulan. Hasil penelitian menunjukkan bahwa benih ikan patin siam yang ditebar di kolam pada umur 5 hari setelah menetas mempunyai laju pertumbuhan spesifik sebesar $11,12 \%$ lebih baik daripada benih ikan patin siam yang ditebar pada umur 10 dan 15 hari setelah menetas, yaitu sebesar $8,41 \%$ dan $8,65 \%$. Namun demikian, bobot individu (9,81-12,32 g), biomassa panen $(118,77-141,91 \mathrm{~kg})$ serta sintasan $(54,53 \%-71,49 \%)$ pada akhir percobaan tidak berbeda nyata.
\end{abstract}

KATA KUNCl: ikan patin siam, pendederan, kolam, umur berbeda

ABSTRACT: Performance of Asian catfish (Pangasianodon hypophthalmus) larvae which plotted in fingerling ponds at three different levels of age. By: Didik Ariyanto, Evi Tahapari, and Sularto

Asian catfish is one of the most populair species in aquaculture. This species was introduced to Indonesia in 1972 and induced spawning was initially in 1981. Since that, fish breeding has rapidly developed by emergence of numerous small-scaled hatcheries. In those breeding system, the larvae were fed with Artemia nauplii at first, followed by Moina, Daphnia, Tubifex and artificial powder feed at the last time. However, since Artemia cyst, Moina, Daphnia, and Tubifex price are quite high and it requires some specialised facilities to produce, it will be the constrain in development of the hatcheries. This study was conducted with the aims to evaluate the performance of Asian catfishes larvae which plotted in fingerling rearing ponds at three different 
levels of age, i.e. 5, 10, and 15 days after hatching. After 60 days in ponds, we evaluated the individual body weight, survival rate and the biomass. The results showed that the individual body weight of three population did not significantly different, but the first population (plotted at 5 days after hatching) has better specific growth rate than others. Not significantly different was not only occurs in individual body weight character, but also in survival rate and the biomass parameters.

\section{KEYWORDS: asian catfish, fingerling rearing, ponds, different levels of age}

\section{PENDAHULUAN}

Indonesia memiliki 14 jenis ikan patin, yang tersebar secara tidak merata di setiap daerah. Tingkat keanekaragaman jenis yang terbesar berada di daerah Sumatera dan tingkat endemis yang tinggi berada di Kalimantan (Gustiano et al., 2003). Salah satu jenis ikan patin yang paling banyak dibudidayakan adalah jenis patin siam. Ikan patin siam (Pangasianodon hypophthalmus) merupakan salah satu ikan introduksi yang telah memasyarakat di Indonesia. Hal ini karena selain mudah dalam budidayanya, ikan patin siam juga mempunyai daya toleransi yang tinggi terhadap kondisi kualitas air yang buruk serta tingkat fekunditas tinggi (Hardjamulia et al., 1987).

Budidaya ikan patin siam mulai berkembang pada tahun 1981, yaitu sejak keberhasilan teknik produksi massal benih secara buatan (Hardjamulia et al., 1987). Selain itu, perkembangan pada usaha pembenihan juga dipicu oleh perkembangan usaha pembesaran. Dalam perjalanannya terjadi segmentasi usaha sesuai kondisi wilayah. Usaha pembenihan berkembang dengan pesat terutama di Jawa Barat (Subang, Bogor dan Sukabumi) serta Jakarta dan sekitarnya, sedangkan sentra pembesaran banyak dilakukan di wilayah Sumatera Bagian Selatan seperti Lampung, Palembang, Jambi, Bengkulu, dan Riau serta sebagian Kalimantan (Sadili, 1998).

Secara umum, teknologi pembenihan khususnya pemeliharaan larva ikan patin siam di Indonesia dilakukan secara indoor hatchery. Secara teknis, kegiatan ini tidak mengalami kendala yang berarti, bahkan sudah dapat dilakukan secara intensif (Ariyanto et al., 2008). Namun demikian, dari segi efisiensi usaha, kegiatan ini membutuhkan biaya yang cukup tinggi. Hal ini karena pakan awal larva ikan patin siam yang biasa digunakan dalam pembenihan sistem indoor berupa nauplii Artemia yang dilanjutkan dengan pemberian Moina dan Daphnia beku serta cacing darah
(Tubifex) sebelum pemberian pakan buatan dapat dilakukan. Optimasi sistem pemeliharaan dan pemberian pakan awal larva ikan patin siam sudah dilakukan antara lain oleh Arifin \& Asyari (1992), Widiyati et al. (1992), Priyadi et al. (1994), Rahayu (2002), Utami et al. (2003), dan Ariyanto et al. (2008). Namun demikian, ketergantungan terhadap ketersediaan beberapa jenis pakan awal larva tersebut sangat dirasakan oleh para pembenih. Hal ini karena perubahan kualitas maupun kenaikan harga jenis-jenis pakan awal larva tersebut berpengaruh terhadap produktivitas dan kelangsungan suatu usaha pembenihan. Banyaknya kendala usaha pembenihan ikan patin siam karena ketergantungan pada jenisjenis pakan alami tersebut menuntut adanya alternatif teknologi pemeliharaan benih tanpa mengurangi kualitas dan kuantitas produk benihnya.

Salah satu teknologi alternatif adalah pembenihan dengan sistem outdoor. Sularto et al. (2008) melaporkan bahwa penebaran larva ikan patin siam berumur 20 jam setelah menetas ke kolam pendederan menghasilkan sintasan kurang dari 30\% setelah dipelihara selama 4 minggu. Rendahnya nilai sintasan benih ini diduga karena umur larva yang ditebar masih sangat muda sehingga rentan terhadap kondisi lingkungan perairan yang fluktuatif maupun terhadap predator yang terdapat di kolam pemeliharaan. Tahapari et al. (2008) juga melaporkan bahwa penebaran di kolam terhadap benih ikan patin siam berumur 3 minggu setelah menetas yang dipelihara selama 6 minggu menghasilkan sintasan lebih baik dibandingkan penebaran larva yang berumur 20 jam setelah menetas, yaitu sebesar 78,10\%-90,83\%.

Secara alami, pakan awal ikan patin baik fitoplankton maupun zooplankton terdapat di lingkungan perairan. Indonesia yang memiliki iklim tropis merupakan tempat yang subur dengan keanekaragaman plankton maupun bentos. Jenis-jenis pakan alami yang tersedia 
di perairan khususnya kolam pemeliharaan ikan diharapkan dapat mengurangi atau menghilangkan ketergantungan pembenih ikan patin siam terhadap jenis pakan awal larva yang biasa digunakan dalam pembenihan sistem indoor.

Dalam rangka mendapatkan teknologi pembenihan ikan patin siam secara outdoor yang efektif dan efisien, kaitannya dengan pemberian pakan awal larva dan kemampuan ikan dalam menghadapi kondisi lingkungan perairan yang fluktuatif, maka evaluasi tentang umur larva yang tepat untuk penebaran di kolam dan keragaannya selama pemeliharaan perlu segera dilakukan. Penelitian ini bertujuan untuk mengevaluasi keragaan larva dan benih ikan patin siam yang dipelihara secara outdoor. Penebaran larva atau benih pada umur yang berbeda diharapkan dapat memberikan gambaran tentang umur ikan yang baik untuk penebaran di kolam. Hal ini terkait dengan daya tahan larva dan benih dalam menghadapi kondisi lingkungan outdooryang relatif lebih tidak terkontrol dibandingkan dengan lingkungan indoor. Selain itu, juga untuk mengetahui kemampuan larva atau benih ikan patin siam dalam memanfaatkan pakan alami yang ada di dalam perairan.

\section{BAHAN DAN METODE}

Bahan utama percobaan adalah larva ikan patin siam yang berasal dari hatcheri ikan patin di Balai Penelitian Pemuliaan Ikan (dahulu Loka Riset Pemuliaan dan Teknologi Budidaya Perikanan Air Tawar), Sukamandi. Larva yang digunakan sesuai dengan perlakuan yang akan diuji, yaitu berumur 5,10 , dan 15 hari setelah menetas. Ukuran bobot dan panjang larva ikan patin siam pada masing-masing kelompok umur disajikan pada Tabel 1.

\section{Metode Percobaan}

Percobaan dilakukan dengan rancangan acak kelompok, 1 faktor dengan 3 taraf perlakuan. Sebagai kelompok adalah kelompok induk yang dipijahkan pada waktu yang berbeda dan perlakuan yang diuji adalah umur larva saat pertama kali ditebar di kolam pemeliharaan, yaitu 5,10 , dan 15 hari setelah menetas. Semua perlakuan diulang sebanyak 2 kali.

\section{Penyiapan Larva}

Larva didapatkan dari pemijahan indukinduk ikan patin siam milik Balai Penelitian Pemuliaan Ikan, Sukamandi. Pemijahan secara buatan dilakukan menggunakan 5 ekor induk jantan dan 5 ekor induk betina mengikuti standard operational procedure (SOP) pemijahan ikan patin siam. Pemijahan induk untuk mendapatkan larva pada perlakuan 15 hari setelah menetas dilakukan terlebih dahulu dilanjutkan dengan pemijahan untuk perlakuan 10 hari setelah menetas dan terakhir pemijahan untuk perlakuan 5 hari setelah menetas. Selisih waktu antara pemijahan 1, 2, dan 3 adalah 5 hari, sehingga waktu penebaran larva di kolam pemeliharaan dapat dilakukan secara bersamaan. Meskipun individu induk yang dipijahkan berbeda antar kelompok waktu pemijahan tetapi masih dalam 1 populasi yang sama sehingga diharapkan mempunyai kualitas yang relatif sama. Hal ini dilakukan untuk menghindari pengaruh perbedaan kualitas induk yang berdampak terhadap kualitas larva yang dihasilkan.

Tabel 1. Ukuran bobot, panjang standar, dan panjang total larva ikan patin siam (Pangasianodon hypophthalmus) pada umur berbeda

Table 1. Range of body weight, standart length and total length of Asian catfish (Pangasianodon hypophthalmus) larvae at three different levels of age

\begin{tabular}{lccc}
\hline $\begin{array}{c}\text { Umur larva ikan } \\
\text { Age of fish larvae }\end{array}$ & $\begin{array}{c}\text { Bobot badan } \\
\text { Body weight }(\mathbf{m g})\end{array}$ & $\begin{array}{c}\text { Panjang standar } \\
\text { Standart length }(\mathbf{c m})\end{array}$ & $\begin{array}{c}\text { Panjang total } \\
\text { Total length }(\mathbf{c m})\end{array}$ \\
\hline $\begin{array}{l}5 \text { hari setelah menetas } \\
5 \text { days after hatching }\end{array}$ & $2.1-66.6$ & $0.8-1.2$ & $0.9-1.4$ \\
$\begin{array}{l}10 \text { hari setelah menetas } \\
10 \text { days after hatching }\end{array}$ & $10.8-122.9$ & $1.3-2.0$ & $1.5-2.4$ \\
15 hari setelah menetas & $9.0-184.0$ & $1.2-2.3$ & $1.5-2.8$ \\
15 days after hatching & & & \\
\hline
\end{tabular}


Larva yang menetas ditampung dan dipelihara dalam akuarium sebelum ditebar di kolam sesuai dengan perlakuan. Larva diberi pakan pertama kalinya pada hari ke-2 setelah menetas. Pakan awal larva ini berupa nauplii Artemia yang diberikan sampai umur 5 hari. Pada umur 5-10 hari setelah menetas, larva ikan diberi pakan berupa Artemia, Moina, dan Daphnia beku serta cacing sutera (Tubivex) segar, sedangkan pada umur 10-15 hari, larva ikan diberi pakan berupa Daphnia beku dan pakan buatan berbentuk serbuk dengan kadar protein pakan $40 \%$. Semua jenis pakan diberikan secara ad satiation dengan frekuensi pemberian setiap 2-3 jam sekali.

\section{Penyiapan Kolam Pemeliharaan}

Kolam yang digunakan untuk pemeliharaan larva ikan patin siam adalah kolam tembok dengan dasar tanah berukuran masing-masing $200 \mathrm{~m}^{2}$. Jumlah kolam yang digunakan sebanyak 6 unit. Penyiapan kolam dilakukan sesuai dengan SOP persiapan kolam meliputi pengurasan air, pengangkatan lumpur, pemberantasan hama menggunakan saponin dengan dosis $200 \mathrm{mg} / \mathrm{L}$, pengapuran dengan dosis $100 \mathrm{~g} / \mathrm{m}^{2}$, pemupukan dengan pupuk organik yang sudah difermentasi sebanyak $200 \mathrm{~g} / \mathrm{m}^{2}$ dan pupuk anorganik urea dengan dosis $3 \mathrm{~g} / \mathrm{m}^{2}$ dan TSP dengan dosis $1,5 \mathrm{~g} / \mathrm{m}^{2}$ serta pengisian air setinggi $60-80 \mathrm{~cm}$. Pemupukan dilakukan 5 hari sebelum penebaran larva ikan dilakukan.

Cara pembuatan pupuk organik fermentasi adalah dengan pembuatan larutan aktivator, terdiri atas $1 / 4$ sendok makan gula pasir dan $4 \mathrm{~mL}$ larutan probiotik yang dicampur dalam $300 \mathrm{~mL}$ air. Larutan ini kemudian dicampurkan ke dalam $10 \mathrm{~kg}$ pupuk organik dan diaduk secara merata. Campuran antara larutan aktivator dan pupuk organik selanjutnya dimasukkan ke dalam kantong plastik tertutup dan disimpan selama 5 hari sebelum diaplikasikan di kolam pemeliharaan ikan.

\section{Pemeliharaan Benih}

Penebaran larva ikan di kolam pemeliharaan dilakukan pada saat sore hari. Pemeliharaan larva ikan dilakukan dengan kepadatan 100 ekor $/ \mathrm{m}^{2}$, sehingga jumlah larva yang ditebar di masing-masing kolam sebanyak 20.000 ekor. Pakan buatan berbentuk serbuk dengan kandungan protein kasar sebanyak $40 \%$ diberikan pada hari ke- 5 setelah pene- baran, khususnya untuk larva yang ditebar pada umur 5 hari setelah menetas. Larva yang ditebar pada umur 10 dan 15 hari setelah menetas, pakan buatan yang sama diberikan pada hari ke-2 setelah penebaran. Pakan diberikan secara ad satiation dengan waktu pemberian 3 kali setiap hari. Pakan buatan berbentuk crumble dengan kandungan protein kasar sebanyak 32\% diberikan mulai hari ke-15 setelah penebaran pada semua perlakuan. Pakan ini diberikan dengan metode dan frekuensi yang sama dengan pemberian pakan serbuk. Pakan buatan ini diberikan sampai akhir kegiatan pemeliharaan, yaitu selama 2 bulan.

\section{Parameter dan Koleksi Data}

Parameter utama percobaan yang diamati adalah data keragaan benih ikan patin siam, meliputi bobot rata-rata individu ikan, sintasan dan biomassa ikan pada waktu panen. Bobot rata-rata individu ikan ditimbang setiap 15 hari sekali menggunakan timbangan elektrik dengan ketelitian 0,01 g. Jumlah sampel untuk analisis bobot rata-rata individu sebanyak 30 ekor dari setiap ulangan yang diambil secara acak menggunakan serokan. Data sintasan ikan dianalisis pada akhir masa percobaan, yaitu dengan menghitung jumlah ikan yang hidup pada saat panen dibagi jumlah ikan yang ditebar pada awal percobaan. Analisis biomassa ikan dilakukan dengan menimbang bobot total ikan pada akhir pemeliharaan. Penimbangan dilakukan menggunakan timbangan digital dengan ketelitian 0,1 g dan dilakukan pada semua ulangan di setiap perlakuan.

Selain data utama, juga dilakukan analisis data pendukung berupa jenis dan jumlah pakan alami di kolam pemeliharaan, jenis dan jumlah pakan alami di saluran pencernaan ikan serta data kualitas fisiko-kimia air media pemeliharaan ikan. Pengambilan sampel air untuk analisis pakan alami di kolam pemeliharaan menggunakan plankton net ukuran $0,11 \mathrm{~mm}$ dilakukan 1 hari sebelum penebaran ikan, sedangkan pengambilan sampel ikan untuk analisis isi saluran pencernaan ikan dilakukan 1 hari setelah ikan ditebar di kolam. Jumlah sampel ikan untuk analisis isi saluran pencernaan ikan sebanyak 5 ekor, yang diambil secara acak dari masing-masing perlakuan dan ulangan. Identifikasi jenis dan jumlah pakan alami di kolam pemeliharaan maupun di saluran pencernaan ikan dilakukan di Laboratorium Limnologi, Lembaga Ilmu Pengetahuan Indonesia (LIPI), Cibinong. 
Analisis kualitas air kolam meliputi suhu, DO, pH, amoniak, dan nitrit dilakukan setiap 2 minggu sekali. Pengukuran parameter kualitas air dilakukan di semua kolam pemeliharaan dengan titik pengambilan sampel pada lokasi yang sama antar kolam.

\section{Analisis Data}

Berdasarkan data bobot individu rata-rata pada awal dan akhir percobaan dilakukan analisis laju pertumbuhan spesifik (LPS) ikan patin siam pada masing-masing populasi. Secara umum, data yang didapat dieksplorasi secara deskriptif untuk melihat kecenderungan hasil yang didapat. Untuk mengetahui perbedaan antar perlakuan, data laju pertumbuhan spesifik, bobot individu rata-rata, sintasan, dan biomassa benih pada akhir percobaan dianalisis secara statistik inferensia menggunakan metode analysis of variance (ANOVA). Jika hasilnya berbeda nyata dilakukan uji lanjutan menggunakan metode Duncan's Multiple Range Test (DMRT) pada kisaran $\mathrm{P}=0,05 \%$ (Sudjana, 1975). Analisis data pakan alami di kolam pemeliharaan maupun di dalam saluran pencernaan ikan serta data kualitas air media pemeliharaan dilakukan secara deskriptif.

\section{HASIL DAN BAHASAN}

Perkembangan bobot individu rata-rata benih ikan patin siam pada masing-masing perlakuan selama 60 hari pemeliharaan disajikan pada Gambar 1.

Gambar 1 menunjukkan bahwa meskipun ukuran larva ikan patin siam yang berumur 5 hari setelah menetas lebih kecil dibanding larva umur 10 dan 15 hari setelah menetas (Tabel 1), populasi ini mampu mengimbangi pertumbuhan 2 populasi lainnya. Bahkan pada hari ke-45 setelah penebaran, populasi tersebut mempunyai bobot individu rata-rata lebih baik daripada populasi yang ditebar pada umur 10 hari setelah menetas. Namun, pada akhir percobaan (hari ke-60), bobot rata-rata individu benih ikan patin siam pada ketiga perlakuan tidak berbeda $(P>0,05)$.

Berdasarkan bobot individu rata-rata benih ikan patin siam pada awal dan akhir percobaan, dilakukan analisis laju pertumbuhan spesifik (LPS). Hasil analisis LPS, bobot akhir rata-rata, tingkat sintasan dan biomassa ikan patin siam pada masing-masing perlakuan disajikan pada Tabel 2. Sebagai pembanding, disajikan hasil penelitian Tahapari et al. (2009) pada pemeliharaan larva ikan patin siam yang dilakukan secara total indoor.

Hasil analisis statistik menunjukkan bahwa bobot akhir, sintasan, dan biomassa ketiga populasi yang dipelihara selama 60 hari di kolam yang dipupuk tidak berbeda nyata $(P>0,05)$. Namun, laju pertumbuhan spesifik karakter bobot individu benih ikan patin siam yang ditebar pada umur 5 hari setelah menetas

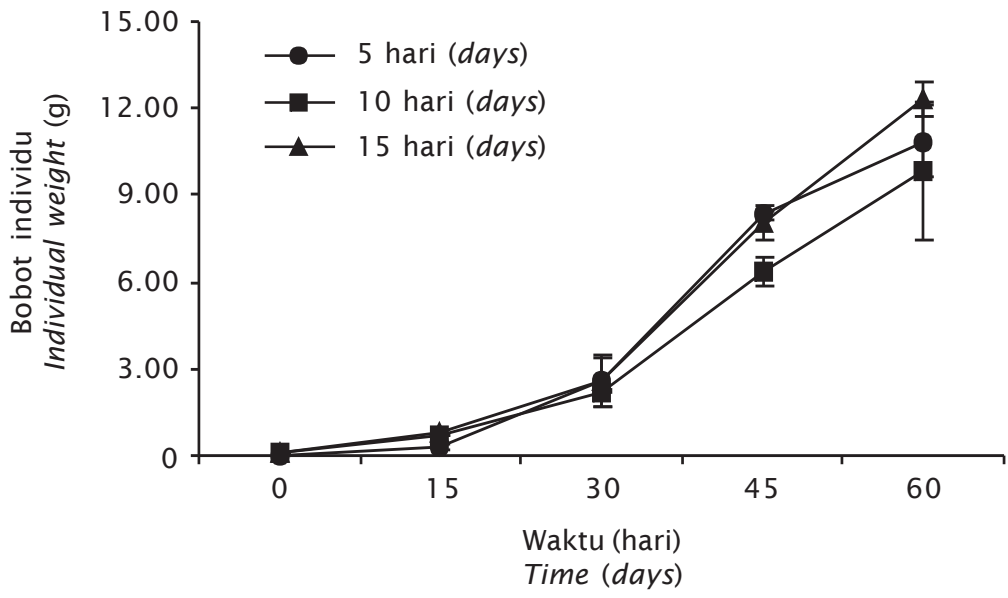

Gambar 1. Pertumbuhan 3 populasi benih ikan patin siam yang ditebar di kolam pendederan pada umur berbeda

Figure 1. Growth performance of 3 populations of Asian catfish which plotted in fingerling ponds in three different levels of age 
Tabel 2. Laju pertumbuhan spesifik (LPS) karakter bobot individu, bobot akhir ratarata, tingkat sintasan dan biomassa benih ikan patin siam yang dipelihara di kolam pendederan selama 60 hari

Table 2. Specific growth rate (SGR), average final body weight, survival rate and biomass of Asian catfish which reared in fingerling ponds for 60 days

\begin{tabular}{lcccc}
\hline $\begin{array}{c}\text { Perlakuan } \\
\text { Treatment }\end{array}$ & $\begin{array}{c}\text { LPS } \\
\text { SGR (\%) }\end{array}$ & $\begin{array}{c}\text { Bobot akhir } \\
\text { Final body weight } \\
\mathbf{( g )}\end{array}$ & $\begin{array}{c}\text { Sintasan } \\
\text { Survival rate } \\
\mathbf{( \% )}\end{array}$ & $\begin{array}{c}\text { Biomassa } \\
\text { Biomass } \\
\mathbf{( k g )}\end{array}$ \\
\hline 5 hari (days) & $11.12 \pm 0.19^{\mathrm{a}}$ & $10.87 \pm 1.26^{\mathrm{a}}$ & $54.53 \pm 1.52^{\mathrm{a}}$ & $118.77 \pm 17.05^{\mathrm{a}}$ \\
10 hari (days) & $8.41 \pm 0.41^{\mathrm{b}}$ & $9.81 \pm 2.37^{\mathrm{a}}$ & $71.49 \pm 27.06^{\mathrm{a}}$ & $133.20 \pm 23.97^{\mathrm{a}}$ \\
15 hari (days) & $8.65 \pm 0.08^{\mathrm{b}}$ & $12.32 \pm 0.62^{\mathrm{a}}$ & $58.02 \pm 16.57^{\mathrm{a}}$ & $141.91 \pm 33.67^{\mathrm{a}}$ \\
Total indoor $^{*}$ & --- & $12.42 \pm 3.42^{\mathrm{a}}$ & $95.56 \pm 1.93^{\mathrm{b}}$ & --- \\
\hline
\end{tabular}

Keterangan (Note):

Nilai \pm standar devisasi. Nilai yang diikuti huruf superscript yang sama pada kolom yang sama tidak berbeda nyata. ": Data sekunder dari Tahapari et al. (2009)

Value \pm standart deviation. The value(s) followed by the same superscript in the same column did not siginificantly different. ": Secondary data from Tahapari et al. (2009)

secara nyata lebih baik dibandingkan kedua populasi lainnya $(P<0,05)$. Jika dibandingkan dengan hasil penelitian Tahapari et al. (2009) pada pemeliharaan larva ikan patin siam yang dilakukan secara total indoor, bobot akhir benih ikan patin siam pada penelitian ini juga tidak berbeda. Pada penelitian ini, nilai sintasan ketiga populasi pada akhir kegiatan berkisar antara 54,53\%-71,49\%. Jika dibandingkan dengan hasil penelitian Tahapari et al. (2009) pada pemeliharaan larva ikan patin siam yang dilakukan secara total indoor yang mencapai nilai $95,56 \%$, nilai sintasan benih ikan patin siam pada percobaan ini lebih rendah. Hal ini karena kondisi lingkungan pemeliharaan ikan patin siam yang dilakukan secara total indoor relatif lebih terkontrol dibandingkan dengan pemeliharaan secara outdoor pada penelitian ini.

Sebagai data pendukung, hasil analisis jenis dan jumlah pakan alami di kolam pemeliharaan serta jenis dan volume pakan alami di dalam saluran pencernaan ikan patin siam disajikan pada Tabel 3 dan 4.

Tabel 3 menunjukkan bahwa semua kolam pada 3 perlakuan mempunyai kelimpahan plankton yang relatif tinggi, yaitu antara 70.200 individu/liter pada kolam dengan perlakuan 15 hari setelah menetas hingga 180.600 individu/liter pada kolam perlakuan 10 hari setelah menetas. Meskipun pada kolam dengan perlakuan penebaran benih berumur 15 hari setelah menetas mempunyai kepadatan plankton paling rendah tetapi mem- punyai keberagaman jenis plankton tertinggi yaitu mencapai 24 jenis sedangkan kolam dengan penebaran benih berumur 10 hari setelah menetas mempunyai keberagaman jenis terendah yaitu 17 jenis saja.

Berdasarkan Tabel 4, terlihat bahwa larva dan benih ikan patin siam mampu memanfaatkan pakan alami yang ada di kolam pemeliharaan, baik fitoplankton maupun zooplankton. Hal ini terlihat dari jenis-jenis pakan alami yang ditemukan di dalam saluran pencernaan ikan pada penebaran umur 5,10 , dan 15 hari setelah menetas. Pada penebaran umur 5 hari setelah menetas, pakan alami yang dominan ditemukan di dalam saluran pencernaan ikan adalah jenis Nauplius sedangkan pada ikan yang ditebar pada umur 15 hari setelah menetas, dominansi pakan alami di dalam saluran pencernaan adalah Daphnia. Hal ini menunjukkan telah terjadi perubahan jenis pakan yang dimakan. Hal ini diduga berkaitan dengan ukuran bukaan mulut larva/benih ikan patin siam pada masing-masing umur.

Sebagai data dukung lainnya, hasil analisis kualitas air media pemeliharaan ikan patin siam meliputi suhu, oksigen terlarut, $\mathrm{pH}$, amoniak, dan nitrit disajikan pada Tabel 5 .

Suhu air kolam selama percobaan merupakan suhu ideal untuk perkembangan ikan patin siam. Kandungan oksigen terlarut dalam media pemeliharaan terendah biasanya terjadi pada dini hari, sesaat sebelum matahari terbit. 
Tabel 3. Jenis dan jumlah pakan alami di kolam pemeliharaan pada masing-masing perlakuan

Table 3. The types and abundance of life foods which be found in each treatment pond

\begin{tabular}{|c|c|c|c|}
\hline \multirow{2}{*}{$\begin{array}{l}\text { Jenis } \\
\text { Genera }\end{array}$} & \multicolumn{3}{|c|}{$\begin{array}{l}\text { Kolam pada perlakuan larva } \\
\text { Ponds with treatments of larvae }\end{array}$} \\
\hline & 5 hari (days) & 10 hari (days) & 15 hari (days) \\
\hline Actinastrum & - & 5.4 & 2.4 \\
\hline Anabaena & - & - & 600 \\
\hline Ankistrodesmus & 3 & 6 & 2.4 \\
\hline Characium & - & - & 600 \\
\hline Chlorella & 2.4 & 10.2 & - \\
\hline Chroococcus & 43.2 & - & - \\
\hline Cosmarium & 2.4 & 3.6 & 600 \\
\hline Crucigenia & 1.2 & - & - \\
\hline Cymbella & 1.2 & - & - \\
\hline Diatoma & 1.8 & - & 1.2 \\
\hline Dictyosphaerium & 1.2 & 4.2 & 7.2 \\
\hline Eudorina & 1.8 & 3 & 1.2 \\
\hline Gloeocystis & 38.4 & - & - \\
\hline Keratella & - & - & 600 \\
\hline Mallomonas & 1.2 & 1.2 & 1.8 \\
\hline Merismopedia & 1.8 & 3 & 1.8 \\
\hline Micractinium & 17.4 & 10.2 & 14.4 \\
\hline Microcystis & 3 & 6.6 & 16.8 \\
\hline Nauplius & - & 1.8 & 600 \\
\hline Navicula & 15 & 88.2 & 2.4 \\
\hline Nitzchia & - & 5.4 & 600 \\
\hline Ochromonas & - & - & 600 \\
\hline Oedogonium & 1.2 & - & - \\
\hline Oocystis & 5.4 & - & 600 \\
\hline Ophiocytium & - & - & 600 \\
\hline Oscillatoria & 8.4 & - & - \\
\hline Pandorina & 1.2 & - & 3 \\
\hline Pediasrum & 1.2 & 4.2 & 600 \\
\hline Phacus & 2.4 & 17.4 & 1.2 \\
\hline Scenedesmus & 3 & 7.2 & 7.8 \\
\hline Selenastrum & - & 3 & - \\
\hline Synedra & - & - & 600 \\
\hline $\begin{array}{l}\text { Jumlah individu } \\
\text { Total of individu }\end{array}$ & 157.8 & 180.6 & 70.2 \\
\hline $\begin{array}{l}\text { Jumlah jenis } \\
\text { Total of type }\end{array}$ & 22 & 17 & 24 \\
\hline
\end{tabular}


Tabel 4. Jenis dan volume pakan alami yang ada di dalam lambung dan saluran pencernaan ikan patin siam pada masing-masing perlakuan

Table 4. The types and volume of life foods which be found in the stomach and digestion system of Asian catfish

\begin{tabular}{|c|c|c|c|}
\hline $\begin{array}{l}\text { Perlakuan } \\
\text { Treatments }\end{array}$ & $\begin{array}{l}\text { Organisme } \\
\text { Organisms }\end{array}$ & $\begin{array}{l}\text { Jenis } \\
\text { Genera }\end{array}$ & $\begin{array}{l}\text { Volume } \\
\text { Volume }\left(\mathrm{mm}^{3}\right)\end{array}$ \\
\hline A (5 hari) & Phytoplankton & Melosira & 0.0016 \\
\hline \multirow[t]{3}{*}{ A (5 days) } & & Glaucocystis & 0.0225 \\
\hline & Zooplankton & Nauplius & 0.0900 \\
\hline & & Tidak teridentifikasi & 0.0315 \\
\hline B (10 hari) & Fitoplankton & Navicula & 0.0078 \\
\hline \multirow[t]{7}{*}{$B(10$ days $)$} & & Melosira & 0.0035 \\
\hline & & Pararella & 0.0020 \\
\hline & & Chlorella & 0.0064 \\
\hline & & Spirotaenia & 0.0014 \\
\hline & & Tidak teridentifikasi & 0.0003 \\
\hline & Zooplankton & Nauplius & 0.0036 \\
\hline & & Tidak teridentifikasi & 0.0016 \\
\hline C (15 hari) & Phytoplankton & Chlorella & 0.0245 \\
\hline \multirow[t]{6}{*}{ C(15 days $)$} & & Closterium & 0.0035 \\
\hline & & Microcystis & 0.0397 \\
\hline & & Scenedesmus & 0.0014 \\
\hline & & Dictyosphaerium & 0.1111 \\
\hline & Zooplankton & Brachionus & 0.0527 \\
\hline & & Daphnia & 0.1845 \\
\hline
\end{tabular}

Tabel 5. Hasil analisis kualitas air media pemeliharaan benih ikan patin siam di kolam Table 5. Analysis of water quality in fingerling ponds of Asian catfish for 60 days period

\begin{tabular}{cccccc}
\hline $\begin{array}{c}\text { Perlakuan tebar } \\
\text { (hari setelah } \\
\text { menetas) }\end{array}$ & $\begin{array}{c}\text { Suhu } \\
\text { Temperat ure } \\
\begin{array}{c}\text { Plotting treatments } \\
\text { (days after hatching) }\end{array}\end{array}$ & $\begin{array}{c}\text { Oksigen } \\
\text { (terlarut } \\
\text { Dissolved } \\
\text { oxygen } \\
(\mathbf{m g} / \mathrm{L})\end{array}$ & $\mathbf{p H}$ & $\begin{array}{c}\text { Amoniak } \\
\text { Ammonia } \\
(\mathbf{m g} / \mathrm{L})\end{array}$ & $\begin{array}{c}\text { Nitrit } \\
\text { Nitrite } \\
\text { (mg/L) }\end{array}$ \\
\hline 5 hari (days) & $27.8-31.4$ & $0.85-9.41$ & $7.59-9.55$ & $0.024-0.039$ & $0.25-0.28$ \\
10 hari (days) & $27.9-31.1$ & $0.94-8.19$ & $8.04-9.50$ & $0.020-0.028$ & $0.29-0.35$ \\
15 hari (days) & $27.9-31.7$ & $0.92-9.84$ & $8.33-9.32$ & $0.017-0.023$ & $0.21-0.27$ \\
\hline
\end{tabular}

Keterangan (Note):

Hasil nilai adalah kisaran dari 2 kali ulangan. Pengukuran dilakukan sebanyak 3 kali, yaitu pada waktu pagi (pukul 5.30), siang (13.00) dan sore (17.00)

The range value resulted from 2 replicates. Analysis was conducted 3 times a day, i.e. 05.30 AM, 01.00 PM and $05.00 \mathrm{PM}$ 
Demikian juga dengan parameter lainnya meliputi $\mathrm{pH}$, amoniak dan nitrit, secara umum masih berada dalam kisaran yang relatif aman untuk pertumbuhan dan perkembangan larva dan benih ikan patin siam.

\section{Pembahasan}

\section{Keragaan Benih Ikan Patin Siam}

Secara umum, laju pertumbuhan larva/ benih ikan dipengaruhi oleh jenis, umur, jenis kelamin dan kepadatan (jumlah atau volume) ikan per satuan luas. Setiap jenis ikan mempunyai laju pertumbuhan yang berbeda. Semakin tua umur ikan, laju pertumbuhan khususnya pertumbuhan spesifik semakin rendah. Pada beberapa jenis ikan tertentu, misalnya ikan tilapia (nila), perbedaan jenis kelamin juga sangat berpengaruh terhadap kecepatan laju pertumbuhannya. Kepadatan ikan per satuan luas tertentu yang lebih tinggi juga akan menurunkan kecepatan pertumbuhan populasi ikan tersebut. Selain faktor internal tersebut, laju pertumbuhan ikan juga dipengaruhi oleh faktor eksternal seperti ketersediaan pakan serta kualitas fisika dan kimia media pemeliharaan (Kamler, 1992).

Lebih tingginya laju pertumbuhan spesifik populasi larva ikan patin siam yang ditebar pada umur 5 hari setelah menetas diduga lebih banyak dipengaruhi oleh umur ikan, kepadatan per satuan luas dan ketersediaan pakan. Perkembangan larva ikan pada umur 5 hari setelah menetas khususnya karakter bobot sangat pesat. Hal ini terlihat pada 2 minggu kedua setelah penebaran, bobot rata-rata individu pada populasi tersebut relatif sama dengan bobot rata-rata individu pada kedua populasi lainnya. Pada periode berikutnya, perkembangan bobot individu ketiga populasi pada percobaan ini relatif sama dan berlangsung hingga akhir percobaan. Selain umur yang berbeda, penyebab lebih tingginya laju pertumbuhan spesifik populasi ikan yang ditebar pada umur 5 hari setelah menetas adalah kepadatan ikan per satuan luas.

Meskipun jumlah benih yang ditebar sama tetapi karena ukuran awal yang berbeda menyebabkan biomassa awal benih yang ditebar pada populasi 5 hari setelah menetas lebih rendah dibanding 2 populasi lainnya. Penebaran ikan dengan biomassa lebih rendah di kolam dengan ketersediaan pakan alami yang relatif sama menyebabkan rasio antara ikan dan pakan menjadi lebih tinggi. Hal ini menyebabkan suplai pakan bagi ikan mejadi sangat berlimpah sehingga berpengaruh terhadap tingginya laju pertumbuhan. Selain biomassa awal yang lebih rendah, tingkat kematian atau kehilangan benih pada populasi yang ditebar pada umur 5 hari setelah menetas juga relatif lebih tinggi. Hal ini diduga juga berdampak terhadap tingginya laju pertumbuhan larva/benih ikan pada populasi tersebut.

Meskipun bobot akhir yang diperoleh pada ketiga populasi relatif sama, namun karena tingkat sintasan pada populasi yang ditebar 5 hari setelah menetas relatif lebih rendah menyebabkan biomassanya menjadi lebih rendah. Lebih rendahnya tingkat sintasan benih pada populasi ini diduga disebabkan oleh umur benih yang masih relatif lebih muda dibanding 2 populasi lainnya. Kamler (1992) menyatakan bahwa semakin muda usia larva atau benih ikan, daya tahannya juga semakin lemah. Hal ini berkaitan dengan belum sempurnanya perkembangan sistem pertahanan dan kekebalan tubuh ikan. Sistem ini akan semakin meningkat seiring dengan bertambahnya umur benih ikan. Hasil penelitian Sularto et al. (2008) pada larva ikan patin siam berumur 20 jam setelah menetas yang ditebar di kolam menghasilkan sintasan 15,4\%-31,2\%. Pada umur tersebut, larva ikan patin siam masih sangat rentan terhadap kondisi lingkungan pemeliharaan yang berfluktuatif serta rawan terhadap predator. Pada umur 5 hari setelah menetas, daya tahan dan daya adaptasi benih terhadap kondisi lingkungan di kolam sudah relatif lebih baik, sedangkan pada umur 10 dan 15 hari setelah menetas kemampuan benih untuk bertahan hidup sudah cukup baik sehingga menghasilkan tingkat sintasan yang relatif lebih baik.

Secara umum, bobot akhir benih ikan patin siam pada penelitian ini relatif sama dengan hasil penelitian Tahapari et al. (2009). Namun demikian, penelitian yang dilakukan secara indoor tersebut menghasilkan nilai sintasan yang jauh lebih baik, yaitu mencapai $95,56 \%$. Kondisi lingkungan pemeliharaan secara indooryang relatif terkontrol diduga menjadi salah satu penyebab perbedaan ini. Selain kondisi lingkungan yang kurang terkontrol, diduga keberadaan predator di kolam juga menjadi penyebab relatif rendahnya tingkat sintasan benih pada penelitian ini. Tahapari et al. (2008) melaporkan bahwa pemeliharaan larva atau benih ikan patin siam secara 
langsung di kolam terbuka relatif rawan terhadap predator seperti gabus, burung pemakan ikan dan sebagainya. Untuk itu, pengembangan pembenihan ikan patin siam sistem outdoor ini perlu mempertimbangkan beberapa hal antara lain: 1) memastikan kolam bebas dari hama sebelum penebaran larva/ benih dilakukan, misalnya dengan pemberian saphonin sebanyak 200 ppm pada saat persiapan kolam, 2) menerapkan sistem filtrasi pada saluran masuk (inlet) dan saluran keluar (outlet) air kolam, 3) membuat pagar pengaman di sekitar kolam yang dapat dibuat dari berbagai bahan seperti bambu, waring dan sebagainya, dan 4) pengamanan terhadap predator berupa burung pemakan ikan dapat dilakukan dengan pemasangan tali atau benang yang dibentangkan di atas kolam. Dengan menjalankan hal-hal tersebut diharapkan kehilangan ikan di kolam yang disebabkan oleh hama dan predator dapat diminimalisasi.

\section{Pemanfaatan Pakan Alami di Kolam}

Berdasarkan pengamatan isi lambung, patin siam yang ditebar pada umur 5,10 , dan 15 hari setelah menetas mampu memanfaatkan jenisjenis pakan alami yang ada di kolam. Pada populasi yang ditebar pada umur 5 hari setelah menetas, pakan alami di dalam lambung dan saluran pencernaan didominasi oleh zooplankton dari jenis Nauplius. Pada umur 10 hari setelah menetas, Chlorella merupakan makanan yang mendominasi isi lambung dan saluran pencernaan ikan hingga mencapai $67,03 \%$. Pada populasi 15 hari setelah menetas, Nauplius sudah tidak ditemukan lagi dalam saluran pencernaan ikan uji, sedangkan Chlorella ditemukan dalam proporsi yang lebih kecil. Pada populasi ini, dominansi makanan didapati pada jenis zooplankton yaitu Brachionus sp. dan Daphnia sp., masing-masing sebesar $14,79 \%$ dan $62,66 \%$. Ukuran dari kedua jenis zooplankton tersebut sesuai dengan bukaan mulut benih ikan patin siam yang lebih besar dibandingkan dengan kedua populasi lainnya. Perbedaan dominansi pakan alami di dalam lambung dan saluran pencernaan ini menunjukkan bahwa sudah terjadi pergeseran pola makan dari Nauplius ke Chlorella, Brachionus, dan Daphnia. Kondisi di atas menegaskan bahwa ikan patin siam merupakan ikan omnivora yang memakan segala jenis makanan baik fitoplakton maupun zooplankton. Jenis makanan yang dikonsumsi disesuaikan dengan umur dan ukuran ikan, kaitannya dengan ukuran makanan dengan ukuran bukaan mulut ikan.

Berdasarkan analisis ini, kelebihan pemeliharaan benih ikan patin siam sistem outdoor adalah pemanfaatan pakan alami yang ada di kolam sehingga tidak memerlukan pakan awal larva yang harus diberikan seperti pada pemeliharaan sistem indoor. Hal ini berdampak terhadap peningkatan efisiensi usaha pembenihan ikan patin siam.

\section{Kualitas Fisika-Kimia Media Budidaya}

Selain berpengaruh secara langsung terhadap laju pertumbuhan, kepadatan ikan secara tidak langsung juga mempengaruhi kondisi lingkungan perairan. Semakin padat ikan yang dipelihara berarti pakan yang diberikan juga semakin banyak. Hal ini mengakibatkan materi buangan akibat metabolisme semakin tinggi. Salah satu akibat yang ditimbulkan adalah menurunnya kadar oksigen $\left(\mathrm{O}_{2}\right)$ terlarut dalam perairan. Oksigen terlarut dalam perairan banyak digunakan untuk oksidasi pakan serta untuk proses nitrifikasi oleh bakteri pengurai (Stickney, 1979 dalam Nurhamidah, 2003). Selain $\mathrm{O}_{2}$ terlarut dalam perairan, parameter lain yang dipengaruhi oleh buangan/limbah akibat pemberian pakan yang tinggi adalah kandungan amoniak $\left(\mathrm{NH}_{3}\right)$ dan nitrit $\left(\mathrm{NO}_{2}\right)$ dalam perairan. Amoniak $\left(\mathrm{NH}_{3}\right)$ adalah hasil dari penguraian protein yang merupakan racun bagi ikan. Boyd (1990) menyarankan agar konsentrasi $\mathrm{NH}_{3}$ dalam media pemeliharaan ikan tidak lebih dari 1 $\mathrm{mg} / \mathrm{L}$. Ditambahkan pula bahwa konsentrasi $\mathrm{NH}_{3}$ dalam perairan juga dipengaruhi oleh $\mathrm{pH}$ dan suhu perairan. Pada $\mathrm{pH}$ normal atau kurang, sebagian besar $\mathrm{NH}_{3}$ akan terionisasi menjadi bentuk $\mathrm{NH}_{4}^{+}$(amonium) yang merupakan senyawa tidak beracun bagi ikan dan biota air lainnya. Namun demikian, pH yang normal dan cenderung asam pada penelitian ini diduga menyebabkan $\mathrm{NH}_{3}$ pada perairan tetap berbentuk amoniak yang bersifat racun. Meskipun kandungan $\mathrm{NH}_{3}$ dalam perairan masih di bawah ambang batas toleransi, keberadaannya diduga berpengaruh terhadap perkembangan benih ikan patin siam. Kandungan amoniak pada kolam dengan penebaran benih berumur 5 hari setelah menetas relatif lebih tinggi dibanding 2 kolam populasi lainnya. Hal ini diduga berpengaruh terhadap tingkat sintasan yang relatif lebih rendah pada populasi tersebut dibanding 2 populasi lainnya. 


\section{KESIMPULAN DAN SARAN}

\section{Kesimpulan}

1. Benih ikan patin siam umur 5 hari setelah menetas dapat langsung ditebar di kolam pendederan sehingga mengurangi ketergantungan terhadap nauplii Artemia.

2. Penebaran benih ikan patin siam pada umur 5 hari setelah menetas menghasilkan laju pertumbuhan spesifik lebih baik dibanding penebaran umur 10 dan 15 hari setelah menetas.

3. Penebaran benih ikan patin siam umur 5 , 10, dan 15 hari setelah menetas menghasilkan sintasan yang tidak berbeda nyata, antara 54,53\%-71,49\%.

\section{Saran}

Pemeliharaan benih ikan patin siam dapat dilakukan di kolam mulai umur 5 hari setelah menetas. Hal ini untuk mengurangi biaya operasional pembenihan terutama penggunaan Artemia sebagai pakan awal larva. Sebagai penggantinya, perlu dilakukan penumbuhan pakan alami melalui pemupukan kolam sebelum penebaran ikan. Selain itu, keberadaan predator seperti gabus, burung pemakan ikan dan lain sebagainya perlu diantisipasi sejak waktu persiapan kolam hingga panen untuk mempertahankan tingkat sintasan benih ikan.

\section{UCAPAN TERIMA KASIH}

Penelitian ini dibiayai oleh Kementerian Riset dan Teknologi melalui Program Insentif di Badan Litbang Kelautan dan Perikanan tahun 2010. Terima kasih disampaikan kepada Ika Nurlela, Supriyanto, dan M. Ichsan Aulia atas segala bantuannya sehingga penelitian ini dapat diselesaikan. Selain itu, terima kasih juga disampaikan kepada segenap staf dan karyawan Lab. Limnologi, LIPI, Cibinong atas bantuannya dalam identifikasi pakan alami. Terima kasih juga disampaikan kepada Mitra Bestari dan kepada Dewan Redaksi atas segala saran dan masukan dalam perbaikan makalah ini.

\section{DAFTAR ACUAN}

Arifin, Z. \& Asyari. 1992. Perawatan larva ikan patin (Pangasius pangasius) dengan sistem resirkulasi. Prosiding Seminar Hasil Penelitian Perikanan Air Tawar tahun 1991/ 1992, hlm. 205-207.
Ariyanto, D., Tahapari, E., \& Gunadi, B. 2008. Optimasi padat penebaran larva ikan patin siam (Pangasius hypophthalmus) pada pemeliharaan sistem intensif. Jurnal Perikanan. X(2): 158-166.

Boyd, C.E. 1990. Water Quality in Pond for Aquaculture. Alabama. Auburn University Press, $482 \mathrm{pp}$.

Gustiano, R., Sudarto, \& Pouyaud, L. 2003. How to recognize Pangasius djambal? In: J. Slembrouck, O. Komarudin, Maskur, and M. Legendre (eds.). Technical Manual for Artificial Propagation of the Indonesian Catfish, Pangasius djambal. IRD-DKP, p. 3-14.

Hardjamulia, A., Prihadi, T.H., \& Subagyo. 1987. Pengaruh salinitas terhadap pertumbuhan dan kelangsungan hidup ikan jambal siam (Pangasius sutchi). Bul. Penel. Perik. Darat. 5(1): 111-117.

Kamler, E. 1992. Early Life History of Fish. Chapman \& Hall. London, 267 pp.

Nurhamidah, D. 2003. Pengaruh padat tebar pada kinerja pertumbuhan benih ikan patin (Pangasius hypophthalmus) dengan sistem resirkulasi. Skripsi pada Fak. Perikanan dan Ilmu Kelautan, Institut Pertanian Bogor, $37 \mathrm{hlm}$.

Priyadi, A., Dharma, L. \& Satyani, D. 1994. Pemeliharaan post larva ikan jambal siam (Pangasius sutchi) dengan pemberian jumlah pakan dan pengelolaan air berbeda. Bul. Penel. Perik. Darat, 12(2): 25-28.

Rahayu, G. 2002. Pengaruh surfaktan deterjen Alkil Sulphate (AS) terhadap larva dan juvenil ikan Patin (Pangasius hypophthalmus). Skripsi pada Fak. Perikanan dan Ilmu Kelautan, Institut Pertanian Bogor.

Sadili, S. 1998. Marketing of Pangasiid catfishes in Java and Sumatra, Indonesia. In : Legendre, M., and A. Parisele (eds.) The biological diversity and aquaculture of Clariid and Pangasiid in South-East Asia. Proceedings of the mid-term workshop of the "Catfish Asia Project". Cantho, Vietnam, 1 1-15 May 1998, p. 21-26.

Sudjana. 1975. Metode Statistika. Tarsito, Bandung, $487 \mathrm{hlm}$.

Sularto, Hafsaridewi, R., \& Tahapari, E. 2008. Pemeliharaan larva ikan patin siam (Pangasianodon hypophthalmus) secara outdoor. Prosiding Teknologi Perikanan Budidaya 2008. Pusat Riset Perikanan Budidaya. Badan Riset Kelautan dan Perikanan, hlm. 125-129. 
Tahapari, E., Ariyanto, D., \& Gunadi, B. 2008. Optimasi pemberian pakan buatan pada pendederan ikan patin (Pangasianodon hypophthalmus) di kolam yang dipupuk. Jurnal Perikanan, X(1): 45-52.

Tahapari, E., Nurlela, I., \& Sularto. 2009. Keragaan pertumbuhan beberapa spesies ikan patin (Pangasius sp.) yang dipelihara secara indoor. Prosiding Forum Inovasi Teknologi Akuakultur 2009. Pusat Riset Perikanan Budidaya. Badan Riset Kelautan dan Perikanan, hlm. 215-220.
Utami, R., Tahapari, E., \& Suhenda, N. 2003. Pengaruh jumlah pemberian pakan alami (Moina sp.) dan lama (hari) pemberiannya terhadap pertumbuhan dan sintasan benih ikan Patin jambal (Pangasius djambal). Seminar hasil penelitian perikanan BRPBAT. Bogor, Desember 2003, $9 \mathrm{hlm}$.

Widiyati, A., Surjoto, V., \& Dharma, L. 1992. Daya tetas telur dan kelangsungan hidup larva ikan jambal siam pada suhu terkontrol. Bul. Penel. Perik. Darat, 1 1(2): 44-49. 